\title{
Erratum: China and Latin America in Transition
}

DOI $10.1057 / 978-1-137-54080-5$

The author bio for Anibal Zottele has been replaced with the below text.

Anibal Zottele is a Professor and researcher at the Universidad Veracruzana (UV), Veracruz, Mexico, from 1977. Professor at the Autonomous Metropolitan University Atzcapotzalco, Mexico, and the National University of Mar del Plata, Argentina. Bachelor of Economics degree from the Universidad Nacional del Sur, Argentina, Master in Business Administration, specializing in Finance, University of Veracruz, Mexico, Ph.D. in Animal Science, Federal University of Minas Gerais, Brazil. Consultant for international organizations of the UN system, financial institutions and state agencies of various countries in Latin America. Research topics: economic development, animal health, political economy, agricultural economics and international trade relations between the countries of Southeast Asia and Latin America. He was coordinator of the Master of Agribusiness at the University of Mar del Plata. He is currently Coordinator of the Center of China-Veracruz Studies, Universidad Veracruzana (http://www.uv.mx / chinaveracruz), and Director of the Magazine Orienting. Tracks East Asia. Society, Culture and Economy. From 1977 to date he has worked as a teacher in matters relating to their areas of specialization at undergraduate and postgraduate level, publishing a large number of articles and books.

(C) The Author(s) 2016 
The updated original online version for this book can be found at DOI 10.1057/978-1-137-54080-5

(C) The Editor(s) (if applicable) and The Author(s) 2016

S. Cui, M. Pérez García (eds.), China and Latin America in Transition DOI 10.1057/978-1-137-54080-5 